\title{
Indigenous School Education and specific teaching-learning processes: reflections based on particular cases of Jê tribes
}

Odair Giraldin ${ }^{1}$

\begin{abstract}
Resumo
A educação escolar indígena disseminou-se entre os povos indígenas do Brasil, tornandose mais ou menos acessível, de acordo com os contextos políticos estaduais e municipais responsáveis pela educação. Os preceitos e regulamentos da Constituição Federal exigem que as escolas indígenas sejam específicas, diferenciadas e bilíngues. Esses preceitos são, em certo grau, confrontados com barreiras socio-culturais impostas pelos responsáveis pela educação escolar indígena que não são indígenas e que, por isso, não possuem o entendimento necessário para desenvolver processos de ensino-aprendizagem específicos para cada povo. Esta fala é uma reflexão sobre esse contexto, baseada em experiências com pesquisas e estudos sobre a educação escolar indígena envolvendo povos Xerénte, Krahô, Pyhcopcatijí, Ràmkokamekrá-Canela e Apinajé. Demonstramos que um entendimento claro do ensino específico do processo de aprendizagem de cada povo é essencial para implementar os preceitos constitucionais relativos à educação escolar indígena.
\end{abstract}

Palavras-chave: Educação escolar indígena, preceitos constitucionais, ensino-aprendizagem, educação diferenciada.

\begin{abstract}
Since the early 90's school education has spread among various indigenous peoples in Brazil, where access to education has been made more or less available according to the political contexts of the State and/or municipal districts that supervise its offer. The constitutional precept and legal provisions ordering that indigenous school education be specific, differentiated, intercultural and bilingual are up to a certain degree confronted with the socio-cultural barriers of the supervisors of the indigenous school education who are not indigenous, and, for this reason, lack the necessary understanding of the specific teaching and learning processes of each people. This lecture will address a reflection of this context, based on experiences with research and further studies on indigenous school education imparted to the Xerente, Krahô, Pyhcopcatiji, Ràmkokamekrá-Canela and Apinajé peoples. We shall demonstrate that a clear understanding of the specific teaching and learning processes of each people is essential to implement the constitutional precept of indigenous school education.
\end{abstract}

Keywords: Indigenous school education, constitutional precepts, processes of learning, differentiated education.

\footnotetext{
${ }^{1}$ Anthropologist - UFT. Researcher of the Brazilian Research Center (Centro Nacional de Pesquisa-CNPq).
} 


\section{Preamble}

When I came to the Apinajé village of São José, in August 1995, its population reached about 600 people. It still preserved the traditional circular shape of the Jê villages, and, on the day following my arrival, I was brought to the yard to participate in a morning meeting and explain the reason and the purposes of my stay. In the yard there was a shed built by Vale do Rio Doce in the 80's, which was used as a garage for the community's truck and pick-up, and also a small school, which had only two classrooms and no secretarial office, nor kitchen or other premises.

In that school, the children of the village studied with the teachers Ana Rosa, Cassiano, Josué and Rosa. The first three were indigenous. Cassiano was paid with a grant from the Indigenist Work Center (Centro de Trabalho Indigenista - CTI); Josué was paid by the missionaries of the New Tribes of Brazil Mission (Missões Novas Tribos do Brasil); Rosa was an employee of the Brazilian Indian Foundation (Fundação Nacional do Índio - FUNAI), and, therefore, she was the only teacher hired by the government of the State of Tocantins.

I lived with the Apinajé for over two years, conducting researches for my doctorate, and at that time, for me, school education was not a matter of ethnographic investigation, because it had little attention from the Apinajé themselves, since school activities only involved children from elementary/ middle school (ranging from 6 to 9 years of age). Children and parents that wished to continue their studies had to go to the nearest town, Tocantinópolis, about $18 \mathrm{~km}$ away (some 12 miles), well into the interior of the Bico do Papagaio region, North of Tocantins State. Since there was a truck in the village (which was left by Vale do Rio Doce in the 80 's), some students were taken daily to that town. However, as a rule the school received very little attention in the daily life of the village.

Thus, my research with the Apinajé dealt with a theoretical issue that caught my attention when I read Relativizando by Roberto da Matta (1993). Initially, I intended to understand how the Apinajé assimilated, felt, rationalized, expressed, and voiced their experience from the times before the arrival of non-indigenous people, since DaMatta stated that "they have a notion of time and duration, but no historical perspective" (DaMatta 1993:121). For DaMatta, having no historical perspective means that the Apinajé would not consider the passage of time as an element that defines their society. All they would have is a former present in which their world was created and a 
current present in which the basic elements of this world are repeated. This discontinuous view of time implies that there are no groups or segments that interpret time and society, and, therefore, there is no forefront of political/ economic/social/artistic development that goes ahead in time (DaMatta 1993:121-124). This theme, as it often happens with anthropological studies and experiences with indigenous people, has changed with field research.

When I started researching, I found out that certain core issues regarding ways of socializing in the Apinajé community had not been fully explained in previous ethnographic studies. As I did my research I came to understand that a fundamental issue in the social relations of the Apinajé was formal friendship. Gradually, I discovered that the means of transmission of this formalized relation had not been fully understood and for this reason, the social implications of this form of social relation had not been interpreted or had been misunderstood. Formal friendship had been seen in the studies of both Nimuendajú and DaMatta, as a structure that would involve three people (Nimuendajú 1983 [1939]:27) or four people placed two by two (DaMatta 1993:138-140). On one side, a social father (or mother) and his or her social child; on the other side, the formal male or female friend and his or her social child of that father or that mother.

I eventually came to understand that, on one side, there is clearly a social father or mother and his or her social child, but the novelty was that, on the other side, there is a group of people consisting of a social father or mother and a group of social children, and more importantly that the blood children of these people are not involved directly in this transmission process. They are, however, fully inserted in the implications of this social relation, since the preferred marriages among the Apinajé occur between a formal friend and a blood child of a formal friend or between blood children of formal friends (Giraldin 2000).

When I started to understand this process, I did not experience the anguish and solitude of the anthropological blues mentioned by Roberto DaMatta, when we make a discovery in field and have nothing but a notebook, a logbook and a few indigenous with whom we can share our discovery (DaMatta 1993:170). Often in field work I had the pleasant company of the linguist Christiane Cunha Oliveira, who carried out researches for her doctorate (Oliveira 2005). She was the person with whom I shared my precious findings. However, I still remember that, once, when I explained the mechanism of formal friendship and its transmission 
to her, we were in the presence of Pãxti (Rosa), widow of Amnhimy/ Katàm Kaàk (Grossinho). After having heard my explanations, in which I used the anthropological jargon, Pãxti stood up and said: "I really cannot understand what you are saying!" And I had to admit I was not certain whether my friend Christiane had also understood my explanations. ${ }^{2}$ But this was mutual. Whenever my friend tried to explain her data on the Apinajé language, using the linguistics jargon, she also was not quite successful. After all, there is a distance between the semantic field of Anthropology and the semantic field of the Apinajé themselves (which was why Pãxti could not understand anything), as well as of Linguistics (which was why Christiane understood very little of what I was saying). Likewise, since my knowledge of Linguistics is restricted to a term of studies in a discipline of introduction to Linguistics offered by the Language Studies Institute (Instituto de Estudos da Linguagem - IEL) of the University of Campinas - Unicamp -, I, in turn, could not understand the breath of her discoveries when she tried to explain what she had been finding in her researches.

\section{Research and school}

These facts indicate that neither for me, and I believe that, nor for Christiane, the village school was perceived as a relevant matter that deserved to be studied at that time by Linguistics or by Anthropology.

Today, however, 15 years after that initial experience with the Apinajé, I am doubly involved with the issue of school education for indigenous people: on one hand, as a professor at the teacher training course for indigenous teachers who live in the State of Tocantins and the undergraduate intercultural course at the Federal University of the State of Goiás (Universidade Federal de Goiás - UFG); on the other hand, I am involved with this issue as I develop researches on the impacts of school education on the indigenous people of Tocantins after 1991 and on the specific teaching-learning processes for the Akwẽ-Xerente, Krahô and Javaé.

At the present, I focus my attention on this subject because a new ethnographic scenario was designed upon the expansion of school education

\footnotetext{
${ }^{2}$ As a matter of fact, even though I have understood the formal friendship, the complexity of this type of sociability has not allowed me, so far, to elaborate a diagram that manages to express all the articulation existing in the formal friendship of the Apinajé. A diagram of this type of sociability can be found in my doctoral thesis (Giraldin 2000:174) available at: http://www.uft.edu.br/neai/ index.php?option=content\&task=view\&id=33.
} 
in the villages. For example, the São José village was fractioned, originating 12 additional villages. As a result, the population decreased. Nonetheless, today, this village has a school with all basic education levels, and four classes have already completed High School. This school has a remarkable physical infrastructure, which even includes a computer laboratory and access to the Internet, a DVD apparatus and a TV set. The school principal is an Apinajé graduate in Pedagogy and several teachers (10) were hired (some through a civil service competitive examination) by the Tocantins State Education Office. Out of the 12 villages originated from São José, five have schools, and one offers basic education up to the $9^{\text {th }}$ year. A school bus hired by the State Education Office drives the students from smaller villages to the São José village school everyday.

This setting outlined for the village of São José can be found in all the other Apinajé villages, and possibly, in all villages of the indigenous people in the State of Tocantins. Among the Krahô, a Regular High School has already been established in the villages of Manuel Alves Pequeno, Cachoeira, Rio Vermelho and Pedra Branca. In the Xerente villages, an Indigenous Xerente High School (Centro de Ensino Médio Indígena Xerente - CEMIX-Warã), as well as two technical - computer and nursery - courses were established in a central area of the territory. Another village (Rio Sono) has also recently established a High School as an extension of the CEMIX. In the areas of the Javaé people, a regular High School was established in the village of São João, and high schools based on the modular teaching system were established in the villages of Txuiri and Canoanã. Moreover, universities have been adopting access policies for indigenous students through the PROUNI or quota system, such as the one existing at the Federal University of the State of Tocantins (Universidade Federal de Tocantins - UFT) since the year 2005, and other similar models that have been implemented at several federal or state universities. Teachers' access to several higher-level teacher training programs, such as the undergraduate intercultural courses at the public Brazilian universities, has also been widened ${ }^{3}$. The current picture highlights school education as an issue that, as Aracy Lopes da Silva already stressed in 2001, deserves anthropological studies. That is, the expansion of the offer of school education for indigenous people in the state and/or municipal districts where this has been happening is a relevant situation

\footnotetext{
${ }^{3}$ Examples of this policy can be found at the courses of the Federal University of Goiás (UFG), the Federal University of Minas Gerais (UFMG), the Federal University of Grande Dourados (UFGD), the State University of Mato Grosso (UNEMAT), the Federal University of Santa Catarina (UFSC), and the State University of Bahia (UNEB), among others.
} 
from an anthropological standpoint, which deserves to be studied based on the specific reference framework and methodologies of the anthropological reasoning and knowledge.

The aim of this anthropological approach is to go beyond the predominance of the pedagogic viewpoint of indigenous school education and to insert, analytically, the indigenous school in wider and multiple social processes and contexts (Lopes da Silva, 2001). Today, we can understand that school has been analyzed from two perspectives, one that seeks to discuss the sociologic approach of the indigenous school and school education as a public policy (Coelho 2008, Paladino 2001 e 2006); the other, which analyzes the indigenous knowledge and education and its relation with cosmology (Cohn 2000 e 2002, Tassinari 2001, Melo 2008). In the latter, the notion of body and person has been the main theoretical tool used (Seeger et al. 1979).

\section{State and political actions for indigenous school education}

When the Federal Government of Brazil, under the authority of the then president Fernando Collor, decided, in 1991, to transfer the school education actions from the sphere of competence of FUNAI to the Ministry of Education (Ministério da Educação e Cultura - MEC), the latter became responsible for financing and elaboration of directives for indigenous school education in Brazil. Based on the so-called system of collaboration among the federate entities (Federal Government, State and Municipal Districts), the Ministry of Education transferred the implementation of school education for indigenous people to the State and Municipal Districts. These in turn received the task, but lacked qualified human resources for its implementation, and the federal government did not even create mechanisms to train qualified administrative staff capable of handling the new situation.

Thus, I understand that, often, the offer of indigenous school education in Brazil fails to take into consideration the main premises established in the Constitution (Art. 210), in the Law of Basic Tenets and Guidelines of National Education (Lei de Diretrizes e Bases da Educação Nacional $L D B E N, 1996$, Art. 32, art. 78), in the National Curricular Reference for Indigenous Education (Referência Curricular Nacional para a Educação Indigena - RCNE-Indigena, 1998) and in the National Education Board (Conselho Nacional de Educação) resolutions (Resolution 03 and Opinion 14): the principle that school must be differentiated, specific, intercultural and bilingual and that the specific processes of teaching and learning of each 
people must be respected. Even though this principle is stated, it is not put into practice very often, because there is a socio-cultural barrier caused by little understanding, by non-indigenous supervisors, of the indigenous school education, of what comes to be the specific teaching and learning process of each people. To me, this difficulty in establishing an effective and democratic communication and argumentation community, as teaches Roberto Cardoso de Oliveira (2000), where the aspirations of the community and its peculiarities are understood and respected, creates obstacles to an effective differentiated education. This dialogue remained asymmetric due to the lack of training of the supervised teachers and the political colonizing attitude of public administrators towards indigenous people. As a result, the State and/ or Municipal Education Offices applied, through these almost twenty years, the general school education guidelines in the offer of universalizing school, with the only difference being the study of mother tongues, art and culture in the curriculum of the indigenous schools. ${ }^{4}$

Thus, as I questioned the supervisors of the indigenous school education in the State of Tocantins, saying that they were disrespecting the indigenous culture by building schools in the villages according to the same models of the schools built outside the village, I was told that the indigenous people demanded similar schools, like those built for white people.

My initial interpretation of this situation was that the indigenous people wanted to have a school like those of white people and not a different school, in order to have access to salaries, school meals and transportation. However, today I reconsider my position, citing the argument of Alcida Rita Ramos (2010), ${ }^{5}$ who affirms that we must further examine the proposal of perspectivist ethnological approaches of seriously taking into account what indigenous people say and think in their theoretical elaborations on themselves and on the non-indigenous world. And what does it mean? It means that we have to understand the reasons why the indigenous leaders did not accept a different school, but wanted a school like those of white people.

\footnotetext{
${ }^{4}$ Let us highlight, however, that in the State of Maranhão, the Krĩkati and Pyhcopcatiji (Gavião [Eagle]) included knowledge on the indigenous rights as a discipline taught in school. In turn, the Krîkati included ethics in place of religion and established that one day of the week should be devoted to art and culture. They elect one theme per year, which is studied and discussed on this day. In this year 2010 the chosen theme was singing.

${ }^{5}$ Text initially presented at a round table (Round Table 25 - Contemporaneous Debates on Indigenous Ethnology) at the VIII Anthropology Meeting of the Southern Cone Common Market (Reunión de Antropología del Mercosur - RAM) "Diversidad y poder en América Latina”. Buenos Aires, Argentina, 2009.
} 
Certainly, this is not a process of alienated assimilation, in the sense that they want to adopt, in all aspects, a white people school in order to abandon their culture and assimilate the other people's culture. I believe that, indeed, they wanted a white people school. After all, for the Jê groups, the most important cultural assets come from abroad and are incorporated - this is a characteristic of these peoples. And knowledge from and on white people can also be understood in this category. But the question is: what were their aspirations towards the school?

During my last field trip to the Apinajé villages, as I followed up on a process of diagnosis for the implementation of the Timbira Ethno-Educational Territory, I asked teachers about the importance of the school village, and most of them answered that school was important to make children smart. This category of the Apinajé means that a smart person is the one who, regardless of the knowledge of the Apinajé culture, can relate with the white people world, talk and write well in Portuguese, and deal with mathematics in order to get to know the Other and protect him or herself. This is still the most important knowledge, because it allows the indigenous to have a fairer relationship with the white man's world (world of the kupẽ). Ultimately, the Apinajé aspire to have a school that provides them with tools to know the white man's world, administer the Other People and be able to relate to them. Perhaps we are dealing with a sort of Reverse Anthropology (Wagner, 2010; Ramos 2010), as they want to use school to get to know non-indigenous people, understand the world of the kupe and avoid being misled by them.

As we shall see below, this was also the project of the Akwẽ-Xerente for their school. In their initial project, they did not take into account the fact that the implementation of non-indigenous school education would forcefully imply abandoning their own traditional knowledge. They considered that this knowledge would continue to be learnt in traditional learning environments. However, with the massification of school education along the lines of universal contents similar to those of schools outside the village, there was an overlap of spheres of competence as school started to take a great amount of time and occupy a very large space in the village everyday life. Concomitantly with the impairment of traditional practices of upbringing Akwẽ individuals (particularly men), the school was gradually incorporated into the village as the main place of education, both for the traditional culture of the people and of non-indigenous knowledge. This massification led to the imposition of subject matters that were not included in the projects of indigenous people, such as Religion, Geography, History, Literature, Physics 
or Chemistry, which led to the perception that, in certain cases, traditional knowledge was no longer needed to be taught.

An argument in favor of the implementation and expansion of offer of indigenous school education with a differentiated approach considered that traditional knowledge should be brought to school in order to rescue their culture and often to preserve their knowledge in writing. This is an entirely mistaken position. Gersem Baniwa (pers. com.) argued that most traditional knowledge, which are fundamental to sustain the lifestyle of several indigenous people, is not to be transmitted collectively but rather individually. As I could perceive from my contacts with the Akwẽ-Xerente, there is knowledge that belongs to clans and is not transmitted by or to other clans. Similarly, esoteric knowledge is a secret of certain individuals which is transmitted individually only to those selected judicially within close relatives, by the very individual that has this knowledge, which is why certain old individuals prefer to die with their knowledge rather than transmit it within a context or to someone that could weaken it.

Nevertheless, this difficulty in supervising indigenous education has shades of differences, depending on the context of activity of the supervisor and on the indigenous people's attitude towards the colonizing state. In the State of Maranhão, the State Education Office has never managed to act effectively in the implementation of indigenous school education. The State Board of Indigenous School Education was established only in 2007 and does not hold meetings very often; consequently, the administrative decisions are made by the supervisors of the State Education Office, with low social control. Thus, the educational supervision logic follows the universalizing principles of the State Education Office applicable to all schools. As a result, constructions are made under the public bidding system and other bureaucratic rules, and the infrastructure of the buildings is always very precarious, following the models of non-indigenous schools. In a few schools there are computers as well as biology, chemistry, physics or any other laboratories for education purposes. Indigenous and non-indigenous teachers alike are hired through a selection process held annually, which begins in February and is only concluded (upon the signing of a contract) at the end of the first term, which leads to impairment of the whole school year. However, due to this "absence" of supervision by non-indigenous people and to this "lack of efficiency" of the supervisors, the indigenous people who live in the State of Maranhão have more control over contents, over school calendar and the school institution itself. 


\section{Indigenous education actions and School Education: the Timbira People}

First of all, let us highlight a few examples. The Pyhcopcatiji (Gavião [Eagle]), the Krîkati, the Krahô and the Canela (Ramkòkamekra and Apànyekra) have various interconnected rituals associated with the formation of the body and the person (personhood) of individuals. These are rituals of reclusion called Ihcrere (Krîkati), Ihkreré (Pyhcopcatiji) and Pẽpjê and Pẽpcahac, practiced by the Canela, which comprise two different periods of reclusion that young men must go through, and also the Catyti (practiced among the Krahô, Pyhcopcatiji and Krîkati), as well as the Ketuwajê. In these periods, not only do young men receive initiation through theoretical access to knowledge, but they also experience a body transformation process, since this is the time when they learn to go through meal regimes that are fundamental to a number of future activities of these young men, be it for the log race or for the development of hunting skills, which includes learning mechanisms of dialogue with animals and other beings of the universe, in order to have a good relationship with these beings, which are, as a matter of fact, considered as other individuals (Soares 2010). It is also this process of reclusion that allows young men to receive initiation in studies of shamanism. And these reclusions apply both to young men and to young women. After all, plantation activities also imply the need to know how to relate with other beings of this environment, since the relation with plants can be as dangerous for women as animals are for men, and, thus, they must establish proper relations with plants.

These Timbira peoples, which still preserve active and politically strong ceremonial and political groups, such as the Prohkam of the Ràmkôkamekra, or whose meetings are still held by men in the yard, as with the Krîkati and Pyhcopcatiji, manage to take a political stand vis-à-vis the positions of the supervisors of the State or Municipal Education Offices. Thus, school activities are kept and vacations take place when boys and girls are in the process of reclusion. Among the Krîkati, for instance, vacations last for three months, during April, May and June, to coincide with the Ihcrere and Catyti. Thus, even if the school education administration is under the control of the Education Office, which has only non-indigenous people to carry out these tasks, the rhythm of school activities in the villages adjust to the traditional rhythm of life. Even if the formation and specific teaching-learning processes are not being observed and followed in the school education practices, they are being used in the traditional formation through rituals of initiation and formation of new bodies and new beings. 
In turn, whenever the non-indigenous supervisors of the indigenous school education are more active and handle the offer more efficiently (from the administrative standpoint of the Education Offices), and this coincides with a people that no longer has strong ethical and moral institutions, then the school rhythm and hours and calendar end up being imposed to the community. Let us analyze the case of the Apinajé, who, as the Timbira groups, traditionally held the Pẽpkaàk and Pẽpkumrenx rites to form new young men. These rituals corresponded to the Pẽpjê and Pẽpcahac of the Canela and to the Ketuwajê and Pẽpcahac of the Krahô. However, in the 30 's and 40 's of the $20^{\text {th }}$ century these rituals were abandoned. ${ }^{6}$ A smallpox epidemic (Nimuendajú [1939] 1983:6) drastically reduced the population, and few young men were left to participate in the Pépkaàk. One of these survivors was a married shaman apprentice who was forced, under his protests, to remain in reclusion. The instructor of this class deceased (possibly of smallpox) before concluding his teachings and the young apprentice was charged with death caused by bewitchment. Afterwards, the social fathers (and mothers) have never risked establishing another class.

Currently, the main ritual activities of the Apinajé are festivities associated with the end of mourning: Mêôkrepoxrundi and Pàrkapể. Moreover, they still strongly preserve the formal friendship institution, which is present in all villages $^{8}$, and people know how to associate formal friends with situations of liminality caused by death. When this happens, one week after burial, blood relatives visit the tomb of the buried individual where they are bathed with a mixture of water and sucupira or gatinhoso tree (hardwoods with strong smell) by their formal friends. These are moments when the transmission of formal friendship occurs, even without a ritual of delivery of ornaments. Another ritual situation in which formal friendship is transmitted is the mẽ amjên. This is a ritual in which a brother of the mother ( $g \hat{e} t$ ) or sister of the father (tyi) of a person tries to inflict upon his or herself an injury suffered by a great nephew

\footnotetext{
${ }^{6}$ Nimuendajú attended and described this ritual in 1937 (Nimuendajú 1983 (1939):34-46).

${ }^{7}$ For a description of these two festivities, please consult my doctoral thesis (Giraldin 2000:225-245).

${ }^{8}$ The Apinajé reservation is located at the municipality of Tocantinópolis, at the extreme north of the State of Tocantins, and may be divided into two main regions, according to the two dominant groups: the region named São José, which is also the name of the main Apinaje village of that region, and the region named Mariazinha, which received its name from the name of the main village of that region. In the villages of São José region there are still groups that practice the ritual of delivery of the ornaments that publicly manifest the relations among formal friends; the same ritual also happens frequently in Botica village, which is located near Mariazinha village.
} 
(tamxwà). For example, if a child was burned with hot water, a gêt or tui will repeat the act, trying to burn him or herself too. Or, if a young man broke his leg playing soccer, his gêt will repeat the act in order to try to suffer the same injury. In this situation, the formal friends of these people are notified and they appear to prevent the consumption of the act. Another important moment is the cutting of hair of the mourning relatives, during the ritual of Pàrkapê or Mẽ okre poxrundi: the moment to close the life cycle of the person who died. It is this act that causes the separation between the world of living people and the world of dead people, leading the mẽ karõ to the dead people village and giving strength to living people.

I could watch one of these rituals in August 2010. Many mothers waited for their children to be released for the afternoon break (at 03:00 pm), so that the children could have their hair cut. However, as the non-indigenous teachers did not want to interrupt class activities, alleging they needed to fulfill 200 school days as defined by the legislation and required by the Education Office and by the Indigenous Supervision Office of the Regional Education Department, at 04:00 pm they had to go personally to school to pick up their children. The leader of the indigenous community (who is also a teacher) and the school principal (who is also indigenous (panhĩ)) had to interfere in order to have the classes suspended and let all the families attend to this and other festivities.

Ritual moments like these are a part of the activities of transmission of traditional knowledge through the songs that are sung during the entire day inside the house that holds the festivity; through the traditional meals that are prepared; through the baskets that are made and through the social relations that are established or reaffirmed by offering gifts to those who are singing or having their hair cut. Ethical and moral values, which will never be transmitted in classrooms, are imparted in these rituals.

When I lived among the Apinajé for the first time, in the mid-90's, daily meetings were held in the yard. All decisions were made in this place for discussion. Today, there are no longer meetings in the yard, maybe also due to the great scission that occurred in the São José village (as explained above). As a result, this political institution was weakened and, the Apinajé no longer manage to confront the power of the State Education Office or of any other state agency.

\footnotetext{
${ }_{9}^{9}$ And I received orders to buy all sorts of beads and cloth for other rituals that will take place next year due to deaths occurring this year.
} 


\section{Actions for indigenous education and School Education: the Akwẽ-Xerente}

Among the Xerente, the institution that formed the ethical and moral bases of youths was the Warã. The last attempts to establish a new class in the warã occurred probably in the 30's or 40's. There is only one elder (Mr. Severo) in the Porteira village who has started but did not conclude the studies in the warã. For the Xerente, Warã refers to the men's house in the center of the yard - where meetings were held - as well as to the institution in charge of the educational upbringing of Xerente men.

According to my own research among the Xerente, with the participation and collaboration of three Xerente university students who received grants, ${ }^{10}$ the traditional education of that people had two traditional spaces of occurrence: the warhizdare and the warã. In the warhizdare (house space and its neighboring area), boys and girls learned, indistinctively, in the household environment with blood relatives and other family members. When a young man reached the category of sipsa (young virgin man), he was taken to the warã, where he went through several learning stages, which the current Xerente researchers compare to the non-indigenous upbringing stages that go from basic to higher-level education. Young men had to go through six stages, and only after having concluded all stages, they were ready for life and marriage (Nimuendajú, 1942:53). Mr. Severo tells that, since he did not conclude the warã, his parents performed his marriage ceremony when he was still a young man (around 20 years old). However, since he had no sexual relations with his wife for one month, his marriage was annulled. Today he explains that he did not feel ready for marriage because he had not concluded the studies in the warã. In fact, only when he reached his $40 \mathrm{~s}$, he did realize that he had not concluded his studies in the warã, and, therefore, he could not have married.

Both in the household (warhizdare) and in the ceremonial (warã) environment, the teaching and learning process was guided by the criteria of interest, observation and repetition, thus stressing the focus of the learning process on the student and on his or her social interactions. In the space of the warã elder instructors carried out activities with the youngsters that were being initiated, in order to provide them with access to knowledge. And these youngsters remained in the warã without any ornament or clothing. They

\footnotetext{
${ }^{10}$ Beneficiaries of grants from the Institutional Program for Scientific Initiation - Affirmative Actions (PIBIC-AF) of the National Board for Scientific and Technological Development of the Ministry of Science and Technology (CNPq).
} 
were taken to places outside the village in order to learn how to hunt, fish and gather, as well as how to cope with cold, heat, hunger and thirst. And each youngster remained at a certain level of learning according to his or her interest, conditions ${ }^{11}$ and capacity to observe and repeat the activities. Thus, this was rather a learning process than a teaching process, since it was focused on the apprentice and on his or her dedication to learning.

This feature of the teaching-learning process of the Akwẽ-Xerente contrasts with the teaching-learning process of non-indigenous people,

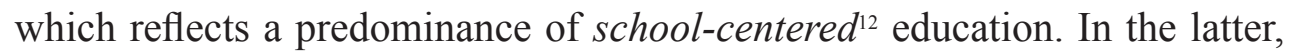
the process is focused on the figure of the teacher that must teach. The teacher is considered an active agent, whereas the apprentice plays the accessory and passive role of learning. And the supposedly suitable environment for this process is the school. The predominance of the school space occurs due to the emphasis on the theoretical aspect of knowledge to the detriment of its practical aspect.

In the specific learning process of the Akwẽ-Xerente, the core aspect lies in pragmatism, since it is by observing the practical experience that apprentices start to build their knowledge. From that point onwards they start listening to the speeches and songs of the eldest with attention. This hearing process implies assimilating through oral transmission and the exercise of memorization of the knowledge acquired. It is in this sense that an elder (Srênomri, 59 years of age) affirms that learning requires a lot of attention. For him, "the ancient indigenous taught that, in order to learn something, one has to have "good ears", sleep late and wake up very early, because it is fundamental to imprint repeatedly in memory what was seen and heard" (Melo 2010:78).

Thus, the Akwe teaching/learning process is centered on the protagonism of the apprentice. Even though it is expressed within the sphere of interest, it is related directly to the practical cognition process mentioned by Lave (1988, apud Codonho, 2007:20). This learning process is the result of a community of practice, it is contextualized socially and related directly to the historical and social context of each people. In addition, the learning process is also based on the cognitive capacities of children, which are considered qualitatively different from the adults' capacities (Toren 1993, apud Codonho 2007:20).

\footnotetext{
${ }^{11}$ Let us remind that there was a great age variation among the members of the same class in the warã.

${ }^{12}$ The notion of school-centered education typical of the western society was inspired in Jean Lave (1982).
} 
Thus, one understands that, among the Xerente, the teacher's attitude is mainly focused on guidance for acquisition of knowledge through practice, but respecting the student's desire to learn.

Currently, Xerente doctorate students under my supervision have reported that the elders strongly criticize the school education existing in the village. When elders favored school education in the past, their idea was not to replace their traditional knowledge with white people's knowledge, but rather have access to white men's knowledge in order to get to know them better and use it as a weapon against white people. However, the interference, initially from the Baptist missionaries and later from the State, in the offer of formal and universalizing education, led to the incorporation of the teachings imparted in the warhizdare into the school program but left aside the ethical and moral knowledge that was transmitted to young men in the wara a Nowadays, the elders have realized that they have lost ground to white people and that non-indigenous knowledge was strengthened, whereas the traditional Akwẽ culture and knowledge was weakened. According to an Akwẽ doctorate student, the teacher training courses were crucial in this process, since the indigenous teachers who, in the past, studied with the elders in order to be able to teach the Xerente cultural values in school, started to be trained in the non-indigenous knowledge and were instructed to impart it in their classes. Gradually, these teachers have drifted away from the elders and remained only with the non-indigenous knowledge. In order to illustrate my viewpoint I quote textually:

With the presence of non-"Indian people" the Xerente lost their own teaching processes which was taught in the warhĩ and in the warã. During the period from 1930 to 1960 , the Xerente ceased to teach in the warã and continued to teach only in the warhĩ. Upon the arrival of the evangelic Baptist mission, the missionaries studied the Xerente mother tongue and culture and prepared a primer in their mother tongue without letting the Xerente lose the habit of teaching in the warhĩ. The Xerente teachers taught what they learned in the warhĩ and non-Indian teachers taught in the Portuguese language to prepare students to attend the nonIndian school outside the village.

When the wawẽ ${ }^{13}$ had their roles as traditional respected leaders, cultural knowledge remained and was practiced by all members of the village. However, the non-indigenous invaders, in order to crush the traditional leading power, created a new system

\footnotetext{
${ }^{13}$ Elders.
} 
of leader called cacique. Thus, they managed to interrupt the tradition and strength of that type of social organization and crush the traditional leadership, so the Xerente could, thus, be integrated into the national communion.

The Xerente elders admit that they failed by allowing the invaders to implement the new system. In the interviews they say that, today, in their majority, the caciques are young, inexperienced, and lacking deep knowledge of the Xerente culture. Thus, the elders think that, for this reason, their people have problems with discussing the pedagogical proposal of building a school education that offers the transmission of the Xerente culture knowledge. All those who were interviewed believe that the teachers only focus on the written aspect of their mother tongue and lack deep knowledge of the Xerente culture (Xerente \& Giraldin 2010).

In fact, in order to get to the condition of being able to teach elements of the traditional culture, it is necessary to become mature with age and through learning processes, such as the warã. There is also the process of maturing which is implied in the whole period of memorization and observation of the traditional speeches given by the elders, in the participation in the organization and development of the traditional activities, as well as in the dialogues established with various elders to further expand knowledge. One of the points noticed by the Xerente researchers is that the elders highlight that, today, the indigenous teachers, besides being too young to teach (not to mention female teachers that cannot teach the knowledge that belonged to the men's house sphere), they have no time for research. One of the Xerente researchers has been, for over two years, interviewing and recording the elders' speeches in order to be able to properly understand the traditional teachings that existed in the warã, in order to try to apprehend what happened after the arrival of the non-indigenous education and school.

The case of the Akwẽ-Xerente helps us to reflect on school education and the role of the advisory services to indigenous schools. On one hand, we can notice that the school education offered to both young men and women establishes a direct connection between the school and the sphere of the wãrhizdare, where boys and girls received teachings from their family members, clearly with distinctive features by gender, but without having knowledge defined as being suitable to only one of the genders. On the other, knowledge addressed exclusively to boys and young men in the warã 
ceased to be taught in school and in the very warã itself. Nevertheless, if the knowledge and the specific teaching and learning processes of the $A k w \tilde{e}$ are to be taken into consideration, the traditional distinctive features that existed should be respected in order to establish a differentiated and specific school.

Similarly, the selection of original myths and narratives to beincorporated in educational school material, for example, may also contribute to enhance only the knowledge imparted within the warhizzdare sphere (intended for both genders) and not the specific knowledge that should be transmitted to each gender individually. It is true that in the first phases of primary school the Akwẽ children of both genders may have access to knowledge that belongs to the sphere of the warhizdare. But, for the following phases, from 9 or 10 years onwards, in order to respect the specific teaching and learning methods of the Akwẽ, the specific educational books should be divided by gender, with different contents according to the conditions of each student. Or books for boys of this phase (corresponding to the age bracket of the Sipsà) should address subjects consistent with the knowledge that the Sipsá received in the warã. In any case, one must seriously take into account what the AkwerXerente say about the school they want and how they want it. Their option should be offered with the best possible quality.

Assessing the school education actually offered to indigenous people led to the conclusion that the insertion of school education in the village, as we have been doing for the past twenty years on the basis of the universalizing model, is not enough to implement a specific and differentiated education. It is necessary to create a specific system of indigenous school education; after all, despite the directives to offer differentiated education, in reality, school education must abide by the requirements of the system existing hitherto: the municipal, state or federal system. All of them follow the same principle of having a minimum curriculum of so-called universal knowledge.

Thus, the indigenous movement established, in the resolutions of the I National Conference on Indigenous School Education, held in 2009, the need for creating a specific system of indigenous school education. The first step was taken upon the enactment of Decree 6861/2009 of the Presidency of the Republic of Brazil, which instituted the Ethno-Educational Territories as a new way of organizing the offer of indigenous school education. Let us hope that, with this new policy, the indigenous peoples' rights will to be more readily respected. 


\section{Conclusion and homage}

My first contact with an indigenous language was in the early 90's, when I was doing research for my master's thesis. I found a list of words of South Cayapó groups in the writings of travelers who came to Brazil in the $19^{\text {th }}$ century, as well as an extensive list of South and Panará Cayapó words collected by a land surveyor and dweller of Uberaba in the early $20^{\text {th }}$ century, called Alexandre de Souza Barbosa, which he collected from a group of dwellers of a village by the Rio Grande river, close to Cachoeira Vermelha. Since I am not a linguist, I was advised by my academic counselor, Prof. Vanessa Lea, to get in touch with Prof. Aryon Dall'Igna Rodrigues and a supervised member of his academic staff, Luciana Dourado, who was studying the Panará language. Based on their analyses, they concluded that the South Cayapó are, from a linguistic viewpoint, the ancestors of the current Panará people (Giraldin 1997). This was fundamental for my interpretations of the documentary information in my possession.

Afterwards, I met my friend and colleague, the linguist Christiane de Oliveira, when we were both doing fieldwork with the Apinajé. Now, I am dealing with indigenous language again, producing pedagogical material for the early years of elementary and middle school for the Akwẽ-Xerente. I have also been translating the book by Curt Nimuendajú The Šerente (1942) from English into Portuguese and into the Akwẽ language. Fortunately, I can now rely on the linguistic skills and knowledge of the written language of the Xerente teachers themselves. These skills were acquired, above all, working with missionaries in the translation of Bible texts, and have been recently complemented at the Undergraduate Intercultural Course of the Federal University of Goiás.

The experience I acquired working on school education and dealing with language issues, showed me the importance of the work of linguists such as Prof. Dr. Aryon Dall'Igna Rodrigues, to whom I would like to pay homage on his 85th birthday.

\section{References}

Codonho, Camila. 2007. Aprendendo entre pares: a transmissão horizontal de saberes entre as crianças indígenas Galibi-Marworno. Dissertação de mestrado, Universidade Federal de Santa Catarina.

Coelho, E. M. B. (org.). 2008. Estado multicultural e políticas indigenistas. São Luís: EDUFMA/CNPq, v. 1. 240 p. 
Cohn, Clarice. 2000. Crescendo como um Xikrin: uma análise da infância e do desenvolvimento infantil entre os Kayapó-Xikrin do Bacajá. Revista de Antropologia 43.2:195-222. São Paulo.

Cohn, Clarice. 2002. A experiência da infância e o aprendizado entre os Xikrin. In: Aracy Lopes da Silva, Ângela Nunes (orgs.). Crianças indígenas: ensaios antropológicos 1:117-149. São Paulo: Global.

Da Matta, Roberto A. 1976. Um mundo dividido: a estrutura social dos índios Apinayé. Petrópolis: Vozes.

Giraldin, Odair. 1997. Cayapó e Panará: luta e sobrevivência de um povo Jê no Brasil Central. Campinas: Ed. UNICAMP.

Giraldin, Odair. 2000. Axpên Pyràk: história, cosmologia, onomástica e amizade formal Apinajé. Tese de doutorado, Universidade Estadual de Campinas.

Lave, Jean. 1982. A comparative approach to educational forms learning processes. Anthropology \& Education Quarterly, special issue, 12.2: 181-187.

Lave, Jean. 1988. Cognition in practice. Cambridge: Cambridge University Press.

Lopes da Silva, Aracy. 2001. Uma "antropologia da educação" no Brasil? Reflexões a partir da escolarização indígena. In: Aracy Lopes da Silva, Mariana K. Leal Ferreira (orgs.), Antropologia, história e educação: a questão indigena e a escola. São Paulo: Global/MARI/FAPESP, pp. 29-43.

Melo, Clarissa Rocha de. 2008. Corpos que falam em silêncio: escola, corpo e tempo entre os Guarani. Dissertação de mestrado, Programa de Pós-Graduação em Antropologia Social, Universidade Federal de Santa Catarina, Florianópolis.

Melo, Valéria M. C. 2010. Diversidade, meio ambiente e educação: uma reflexão a partir da sociedade Xerente. Dissertação de mestrado, Universidade Federal do Tocantins.

Ministério da Educação e Esportes. Secretaria da Educação Fundamental. 1998. Referencial curricular nacional para as escolas indígenas. Brasília: Ministério da Educação, Secretaria de Ensino Fundamental.

Nimuendajú, Curt. 1983 [1939]. Os Apinayé. Belém: Museu Paraense Emílio Goeldi.

Nimuendajú, Curt. 1942. The Šerente. Los Angeles: The Southwest Museum.

Oliveira, C. Cunha de. 2005. The language of the Apinajé people of Central Brazil. Ph. D. dissertation, University of Oregon. 
Oliveira, Roberto Cardoso de. 2000. O trabalho do antropólogo. São Paulo: Unesp; Brasília: Paralelo 15.

Paladino, Mariana. 2001. Educação escolar indígena no Brasil contemporâneo entre a revitalização cultural e a desintegração do modo de ser tradicional. Dissertação de mestrado, Programa de Pós-Graduação em Antropologia Social, Museu Nacional, Universidade Federal do Rio de Janeiro.

Paladino, Mariana. 2006. Estudar e experimentar na cidade: trajetórias sociais, escolarização e experiência urbana entre jovens indígenas Ticuna, Amazonas. Tese de doutorado, Programa de Pós-Graduação em Antropologia Social, Museu Nacional, Universidade Federal do Rio de Janeiro.

Ramos, Alcida Rita. 2010. Revisitando a etnologia brasileira. In: Luiz Fernando Dias Duarte (org.), Horizontes das ciências sociais: antropologia. São Paulo: ANPOCS, Barcarolla, Discurso Editorial.

Soares, Ligia R. R. 2010. Amji kĩn e pjê cunẽa: cosmologia e meio ambiente para os Ràmkôkamekrá/Canela. Dissertação de mestrado, Universidade Federal do Tocantins.

Tassinari, A. M. I. 2001. Escola Indígena: novos horizontes teóricos, novas fronteiras de educação. In: Aracy Lopes da Silva, Mariana K. Leal Ferreira (orgs.), Antropologia, história e educação: a questão indígena e a escola. São Paulo: Global/MARI/FAPESP, pp. 44-77.

Toren, C. 1993. Making history: the significance of childhood cognition for a comparative anthropology of mind. Man, n.s., 28.3:461-478.

Wagner, Roy. 2010. A invenção da cultura. São Paulo: Cosac Naify.

Xerente, V. Sumekwa, O. Giraldin. 2010. Os efeitos da ampliação do acesso à educação escolar na transmissão da cultura Akwẽ-Xerente. Anais do IV Seminário Internacional Fronteiras Étnico-Cultural e Fronteiras da Exclusão. Campo Grande: UCDB. 